\title{
Testing arbitrary classes of light in a physiognomically heterogeneous area of "campo rupestre" vegetation
}

\author{
ANA S.F.P. MOREIRA ${ }^{1}$, EDUARDO L. BORBA ${ }^{2}$ and JOSÉ P. LEMOS-FILHO ${ }^{3}$ \\ ${ }^{1}$ Instituto de Biologia, Universidade Federal de Uberlândia (UFU), \\ Av. João Naves de Ávila, 2121, 38400-902 Uberlândia, MG, Brasil \\ ${ }^{2}$ Centro de Ciências Naturais e Humanas, Universidade Federal do ABC (UFABC), \\ Rua Santa Adélia, 166, 09210-170 Santo André, SP, Brasil \\ ${ }^{3}$ Departamento de Botânica, Instituto de Biologia Geral, Universidade Federal de Minas Gerais (UFMG), \\ Av. Antonio Carlos, 6627, 31270-901 Belo Horizonte, MG, Brasil
}

Manuscript received on June 30, 2011; accepted for publication on June 11, 2012

\begin{abstract}
The Brazilian "campo rupestre" vegetation shows high light heterogeneity, characteristic which is often disregarded in ecophysiological studies due the difficult of obtaining accurate measurements in a complex environment. The aim of the present study it was to describe how much heterogeneous is the light distribution in this environment, as well as tried to define classes in relation to the photosynthetically active radiation (PAR) for 30 rupicolous individuals of Bulbophyllum involutum. The individuals were marked and previously classified in light classes visually predetermined ("full sun", "partially shaded" and "shaded"). Once defined these classes, principal component analysis, cluster and dispersal analyses using direct and indirect PAR measures were performed to characterize the environment as well as to validate the inclusion of the individuals in each class. The use of multivariate analysis increased the accuracy of predetermined classes of light, and some individuals from "shaded" and "partially shaded" classes needed to be regrouped. After individuals" reclassification, amplitude of PAR variance was reduced in each class, enhancing homogeneity. Ours results show the possibility to evaluate light environment conditions more precisely in "campo rupestre" vegetation using multivariate analysis, allowing the increase in accuracy of this parameter for ecophysiological researches.
\end{abstract}

Key words: Bulbophyllum involutum, habitat, light heterogeneity, multivariate analysis, Orchidaceae, rocky outcrops.

\section{INTRODUCTION}

The light variation observed in heterogeneous environments requires precise characterization in order to determine their effects on plant ecophysiology. In a temporal context, as higher is the species richness of an area, larger is the possibility

Correspondence to: José Pires de Lemos-Filho

E-mail: jlemosfilho@hotmail.com of phenological changes that alter light environments along the year. Additionally, the quantification of any physical variable in a heterogeneous environment, such as photosynthetically active radiation (PAR), usually requires relatively expensive sensors and equipments (Brown et al. 2000), and it is time consuming (Gendron et. al. 1998). Direct methods used to quantify light 
generally only function over short time spans and the sensors can be placed in only a few sites at a time (Engelbrecht and Herz 2001, Gendron et al. 1998). The use of traditional methods of direct light measurements is compounded in habitats in which the topography hinders the movement of researchers, especially when the number of sensors is limited. A greater number of sensors would be necessary to meet the demand to assess more accurately the heterogeneity of light. The indirect methods, such as hemispherical photographs and LAI 2000 Plant Canopy Analyser, quantify the differences between gaps of different sizes and the canopies. They are most frequently used in forest formations (Brown et al. 2000, Engelbrecht and Herz 2001), and are less time consuming (Gendron et al. 1998). Hemispherical photographs are useful to record obstructions to light caused by vegetation or by topography interferences (Mitchell and Whitmore 1993). Through hemispherical photographs is possible to analyse the temporal variation in the contribution of sunlight within a day and during the year. Thus, a single photograph taken at the correct time can be used to calculate the radiation at a variety of time scales, from an instant to a continuous (Mitchell and Whitmore 1993).

High environmental heterogeneity is found in the Brazilian "campo rupestre" vegetation (Caiafa and Silva 2007, Derby 1961, Oliveira-Filho et al. 1989), but there are no studies evaluating light heterogeneity in this vegetation type. This formation occurs at altitudes above $800 \mathrm{~m}$ and consists primarily of a more or less continuous herbaceous level growing on rock outcrops, with many small sclerophylous shrubs and subshrubs with perennial leaves growing in crevices or in other sites that have shallow soil. In Minas Gerais state, "campo rupestre" vegetation is often surrounded at lower altitudes by "cerrados" (savanna vegetation), and on the more humid slopes of these mountains there are usually scattered areas of semi-deciduous forests. "Campo rupestre" vegetation is not a homogeneous vegetation type, but rather a complex mosaic of environments with distinct physical characteristics that are determined by the local topography, slope, microclimate, and the nature of the substrate (Giulietti et al. 2000, Oliveira-Filho et al. 1989, Rizzini 1976, Scarano 2007).

The spatial heterogeneity, such as natural illumination, can be of biotic or abiotic origin (Wilson 2000). In the first case, the architecture of the covering vegetation, and its phenological variation, plant illness or herbivory affecting the individuals that comprise that covering, may generate variation in the intensity and quality of the radiation incident on smaller organisms growing near ground level (Quilchano et al. 2008, Wirth et al. 2001). Abiotic factors, such as topography and slope, may also play very important roles in diurnal and seasonal variation of environmental illumination (Wilson 2000).

Due to the environmental heterogeneity of "campo rupestre" vegetation, both data collection and characterization of the local environment are frequently quite difficult (Caiafa and Silva 2007), constituting an obstacle for field studies while also reducing the precision of the data in relation to the environmental variables examined. Considering the heterogeneity of the vegetation mosaic that makes up the "campo rupestre" vegetation, some questions concerning the seasonal and spatial distribution of light were taken: How heterogeneous is the light distribution in this environment?; In view of the physiognomic heterogeneity described for this formation, is it possible to define discrete niche classes in relation to the photosynthetically active radiation (PAR)?; Once these classes are defined, can all of the individuals of a population be included on them? In order to evaluate the heterogeneity of photosynthetically active radiation distribution in areas of "campo rupestre" vegetation, we examined individuals of Bulbophyllum involutum Borba, Semir \& F. Barros (Orchidaceae) growing under distinct light environments in the region of 
Taboões - Serra do Caraça, municipality of Catas Altas, Minas Gerais state, southeastern Brazil. Bulbophyllum include a group of species that distinguished by vegetative diversity, with leaves ranging in size (between 1 and $15 \mathrm{~cm}$ ), succulence and shape (plane to terete) (Smidt 2007). From the physiological point of view, Bulbophyllum has photosynthetic pathway highly variable, with $\mathrm{C} 3$, C3-CAM intermediate, and CAM species (Arditti 1969, Winter et al. 1983). The occurrence of $B$. involutum in a heterogeneous light environment raises some questions about ecophysiological strategies for the large distribution of the genus and the distinct conditions that they live in. However, for these kind of studies an accurate environment characterization is required. In this sense, this study aimed to determine an effective methodology to classify individuals in a population of $B$. involutum as the light in which they are exposed, quantifying the PAR within the classes. Three light classes ("full sun", "partially shaded", and "shaded") were visually established a priori and the light was evaluated using quantum sensors as a direct method and hemispherical photographs as an indirect method. Multivariate analyses were used to examine the viability of the inclusion of individual plants into each class.

\section{MATERIALS AND METHODS}

\section{STUdy AREA AND Plant MATERIAL}

The Serra do Caraça region is located in the southern part of the Cadeia do Espinhaço Mountain Range (Ferreira et al. 1977/1978). The soils are generally shallow with frequent quartzite outcrops (Franco and Endo 2004, Benites et al. 2007). The local climate is classified as type Cwb by the Köppen-Geiger climatological system, having mild and rainy summers with average annual precipitation rates above $1,500 \mathrm{~mm}$ and mild average temperatures throughout the year $\left(18^{\circ} \mathrm{C}\right.$ to $19^{\circ} \mathrm{C}$ ) (Brandão et al. 1994, Dutra et al. 2002).
The study area is located near Taboões region, Serra do Caraça, in the municipality of Catas Altas, Minas Gerais state, Brazil $\left(43^{\circ} 30^{\prime} 11.2^{\prime \prime} \mathrm{W}\right.$; $20^{\circ} 05^{\prime} 00.3$ 'S). It is characterized by irregular topography and "campo rupestre" vegetation in a site with the predominance of exposed outcrops having many crevices and fissures. At the highest point of the outcrop there are small evergreen arboreal formations, formed by species with different degrees of deciduousness. All analyses were performed between July 2006 and July 2008, and data gathering were made during four seasons of the year: the peak of the dry season (July 2006), the start of the rainy season (October 2006), the peak of the rainy season (January 2007), and start of the dry season (May 2007). Air temperature and humidity were monitored during one day of each season between 7 am and 6 pm using a Datalogger (Li-Cor, LI-1400). The minimum temperature of $13^{\circ} \mathrm{C}$ was registered in July and the maximum of $37^{\circ} \mathrm{C}$ in May. Relative humidity of the air varied between $13 \%$ and $78 \%$ in July, $40 \%$ and $80 \%$ in October, and $15 \%$ and $68 \%$ in May. There were heavy rains in summer mainly during January.

A population of Bulbophyllum involutum was used as a study case. It is a rupiculous endemic species from the "campo rupestre" vegetation of the Cadeia do Espinhaço Mountain Range in the states of Minas Gerais and Bahia, generally growing between 600 and 1,300 m (Smidt 2007). Although these plants are preferentially rupiculous (Smidt 2007), they can also grow as epiphytes in arboreal formations near outcrops. These orchids are found growing on rocks exposed to direct sunlight, or scattered among subshrubs and shrubs, occupying niches that apparently are exposed to high light amplitude.

\section{FIELD STUDIES AND EXPERIMENTAL DESIGN}

Thirty individuals of $B$. involutum were initially selected and classified according to their apparent 

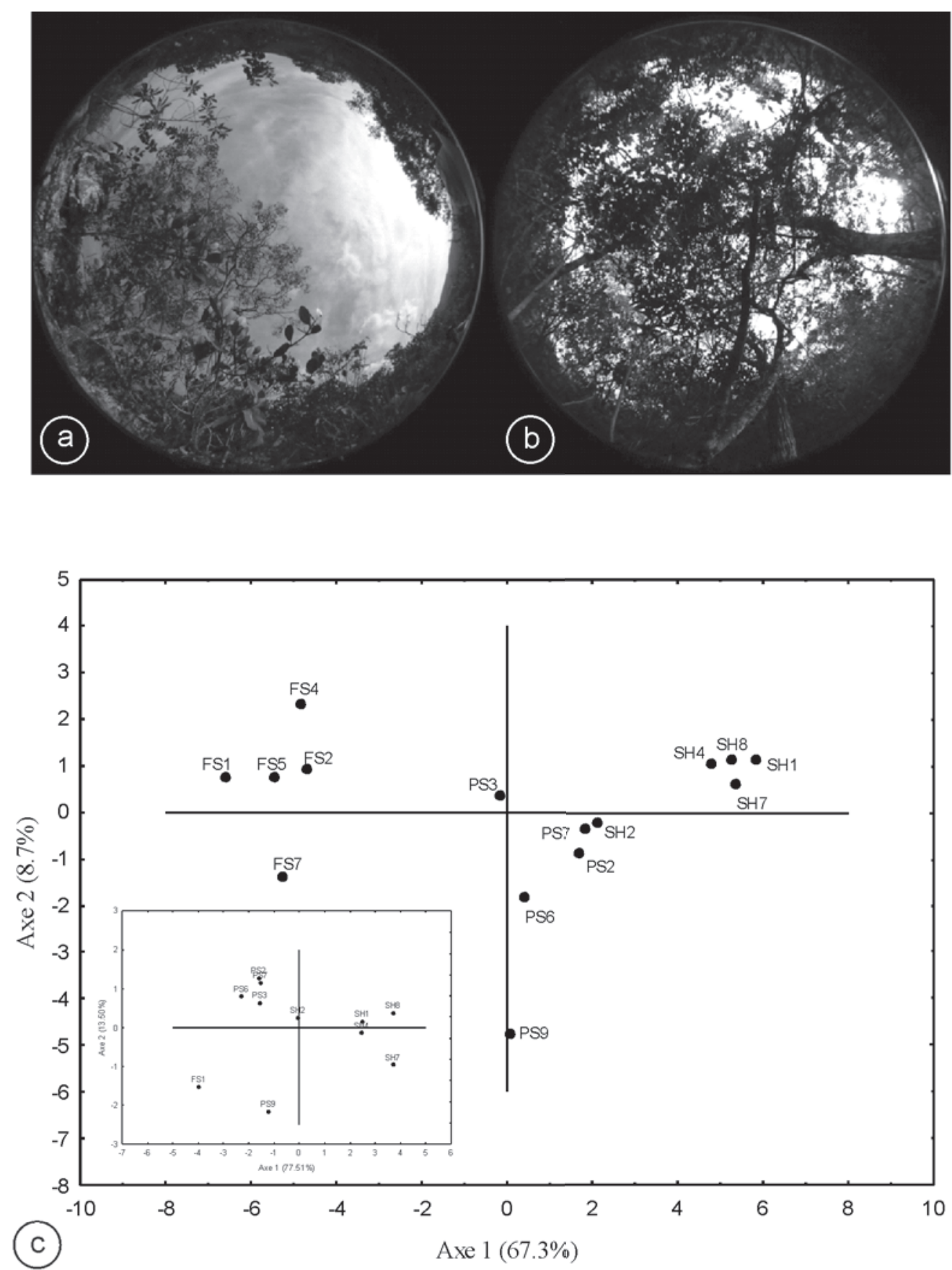

Fig. 1 - Hemispherical photographs taken below two individuals of Bulbophyllum involutum (Orchidaceae) belonging to the "partially shaded" (a) and "shaded" (b) classes within a population growing in the Serra do Caraça mountains, Catas Altas, Minas Gerais State, Brazil. See text for definition of the light classes. (c) Representation of the scores on axes 1 and 2 in a principal component analysis (PCA) utilizing the total daily photosynthetically active radiation (PAR) incident on 15 individuals of a Bulbophyllum involutum (Orchidaceae) population growing in the Serra do Caraça mountains, Catas Altas, Minas Gerais State, Brazil during one day in the months of July and October of 2006, and May/2007. Light classes: "full sun" (FS), "partially shaded" (PS) and "shaded" (SH). See text for definition of the light classes. 
degree of exposure to sunlight. To determe a priori classes, we marked by chance the first 10 individuals belonging to the "full sun" class (exposed directly to the sun), the first 10 individuals belonging to the "partially shaded" class (growing among subshrubs and shrubs or in crevices in the surface rocks), and the first 10 belonging to the "shaded" class (growing under shrubs or arboreal formations) (Fig. 1a, b).

Photosynthetically active radiation (PAR) was directly monitored between 8 am and 6 pm every hour, individual by individual, in July and October 2006, and in May 2007 using a quantum sensor (LiCor, USA). It was not possible to monitor the PAR in January 2007 due to the heavy seasonal rains. The hourly interval between each measurement was chosen to attempt an accurate characterization of the PAR incident on the plants during the day. Due to the rough topography of the outcrop in the study area, however, it was impossible to measure the PAR at all 30 individuals in less than 15 minutes. As an alternative, a transect was laid out linking the two most distant individuals in the sample, and the five individuals belonging to each illumination class that were located nearest the transect axis were included, with a total sample size of 15 individuals. This procedure allowed us to monitor the PAR of each class within a maximum of five minutes intervals.

In order to test the proposed methodology and to check the reliability of the results obtained in the previous year, light was also indirectly determined based on hemispheric photographs taking next to each individual belonging to the "partially shaded" and "shaded" classes ( $n=10$ per class). As the "full sun" class demonstrated the least heterogeneity by the direct monitoring method, only one individual of this class was analyzed using this indirect technique. This individual was located near a rock surface that might shade it from direct sunlight at some point during the day. However, analysis of the hemispherical photograph indicated that this obstacle would not interfere with the incident light.
The photographs were taken using a Nikon digital camera (Colpix 5400) placed as near as possible to ground level (as the individuals of $B$. involutum were all less than $30 \mathrm{~cm}$ tall). A fish-eye lens with $180^{\circ}$ field of vision (Nikon Fc-E9) was coupled to the camera and horizontally levelled, and the camera positioned in relation to the magnetic north. Photographs were taken during May and July, the months with the greatest observed light heterogeneity by direct measurements, soon after sunrise or at sunset - the hours with the greatest homogeneity of illumination that allows the best contrast for analysis of the photographs. The photographs were analyzed using the Gap Light Analyzer (GLA) software program (vs 2.0, Simon Fraser University, Canada, and the Institute of Ecosystem Studies, USA), with corrections in relation to true North. It was obtained the values of the leaf area index (LAI), the direct and the diffuse light transmittance percentage. A linear regression was adjusted to test the relationship between the light obtained from direct method and hemispherical photographs using Microcal Origin software (version 6, Northamptom USA).

The light heterogeneity impinging on individuals of $B$. involutum was estimated by calculating its coefficient of variation (CV) (Quilchano et al. 2008) using data relative to the total daily PAR (estimated using the sum of the mean of the values obtained on each interval of light measured -8 and 9 hours, 9 and 10 hours, etc - multiplied by 3,600 seconds), the leaf area index (LAI), and the percentages of direct and diffuse light transmittance. CV was calculated using the PAR incident on five individuals of each class. Data were expressed in percentage. Statistical analyses were performed using the JMP software program (SAS Institute, USA, 1989-2002). Normality and homoscedasticity were tested, and the normal data were submitted to ANOVA, compared by Tukey's test. Non-parametric Kruskal-Wallis test (Zar 1999) was applied to the rest of the data. 
In order to evaluate the validity of the inclusion of individuals in each three a priori visually established light classes, principal component analyses (PCA), cluster and dispersal analysis were carried out using Statistica 6 (StatSoft 2003) and PAST (Hammer et al. 2001) software. The PCA were performed to indicate the amplitude of light which the $B$. involutum individuals grown and a possible separation of light conditions. The correlation matrix was constructed using raw data as variables the hour by hour point values of the PAR during one day in May, October, and July, daily total of this incident radiation, and hemispherical photographs data (LAI, direct and diffuse light transmittance). The number of axes interpreted was determined by the variability associated with each axis and by the autovalues. Clustering analysis was performed to form groups based on incident light (using daily total PAR, instantaneous values - hour in hour - of PAR, and hemispherical photographs data - LAI, direct and diffuse light transmittance), using Morisita as the coefficient of similarity, and UPGMA (Unweighted Pair-Group Method using Arithmetic Averages) as the clustering algorithm.

After multivariate analysis of the data obtained with the first 15 individuals, the limits of three light classes were defined. In order to confirm the inclusion of the remaining 15 individuals (which had not been measured previously) into these light class, they were monitored with a quantum sensor every two hours for one day. The measurements were performed at larger time intervals in order to verify the viability of the earlier analyses of the first 15 individuals with less physical effort, and to determine if other possible field measurements could be performed simultaneously. To facilitate the measurement of individuals located more distant from the transect (and/or more difficult to reach), two quantum sensors calibrate previously were used (Li-Cor, USA).

A second 120 meter-long transect was established from the base $(1,192 \mathrm{~m}$ alt.) to the highest point $(1,225 \mathrm{~m}$ alt.) of the outcrop to estimate the relative abundance of each light class in the population. The genets found up to $1 \mathrm{~m}$ on each side of the transect were counted and visually included in the classes "full sun", "partially shaded", or "shaded". This classification was carried out taking in consideration the reclassifications needed as pointed out in the multivariate analyses, caused by environmental factors (covering species, area topography and slope, etc.). Because PAR data were gathered for these individuals, possibly some mistake in inclusion of the classes may have occurred. But, based on the results of the analysis, we believe that they may be small and not affect the overall objective of this estimate.

\section{RESULTS}

\section{DETERMINING INDIVIDUAL Light CLASSES}

Principal component analysis (PCA) based on the total daily PAR from direct method of the first five individuals of each light class resulted in only two axes with significant information $(67.3 \%$ of all variance) (Fig. 1c). The first axis $(58.6 \%$ of the variance) separated the individuals in a manner compatible with the a priori classes, with five individuals associated by the high light incidence throughout the year and four associated by the low light conditions in the extremes of the axis. A third set composed by the individuals initially classified as "partially shaded" plus one previously included in the "shade" class (individual SH2) occupied a intermediate position on the axis. The axis 2 ( $8.7 \%$ of the variance) showed the individuals to be largely dispersed, with overlapping among the three a priori classes, and did not contribute to distinguish between them. It was possible to observe, however, that individuals belonging to the "partially shaded" class were the most widely dispersed (especially individual PS9, which received less than $10 \mathrm{~mol} \cdot \mathrm{m}^{-2} \cdot \mathrm{day}^{-1}$ of PAR in May). The PCA using hemispherical photographs 
light data were similar to the direct method one (small square fig. 1c). This result was expected, since there was a significant linear relation between light obtained from direct measurement using quantum sensors and the total light estimated from hemispherical photographs analysis $\left(\right.$ Light $_{\text {dir }}$ $=9.51+0.53$ Light $\left._{\mathrm{hp}}, \mathrm{r}^{2}=0.746, \mathrm{p}<0.0001\right)$.

The cluster analysis undertaken using the total daily PAR (Fig. 2a) showed two main groups, the first one composed of individuals classified $a$ priori as "shaded". The second group included the "full sun", "partially shaded" individuals, and SH2 individual. These individuals were distributed into two subgroups, the first being composed by individuals classified as "full sun" plus PS9, and the second one composed by individuals classified as "partially shaded" plus the individual SH2, classified as "shaded". In the "full sun" group, the individual PS9 stood out as being linked externally to the other individuals in its class, which could be interpreted as a third unitary subgroup. These groups were also evident in the dendrogram generated using the instantaneous values (hour in hour) of PAR (Fig. 2b), in which the same PS9 individual stood away from the group composed by individuals belonging to the class "partially shaded" and "shaded". The large linkage distance between the "partially shaded" individuals, as well as the large dispersion observed in the PCA, indicated the high amplitude of light where they occur. The cluster composed by "shaded" individuals (with the exception of SH2) constitutes a cohesive group and presented the smallest linkage distances. The same topology of both dendrograms was observed using other grouping algorithms, such as Single Linkage and Complete Linkage (data not shown). However, the total daily PAR showed groups with smaller distances between the components than was seen using point values of PAR. The dendrogram obtained from hemispherical photographs data showed similar structure, with more evident groups, and emphasizing the inclusion of individual $\mathrm{SH} 2$ in "partially shade" group (Fig. 2c).

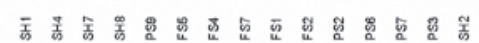



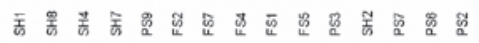

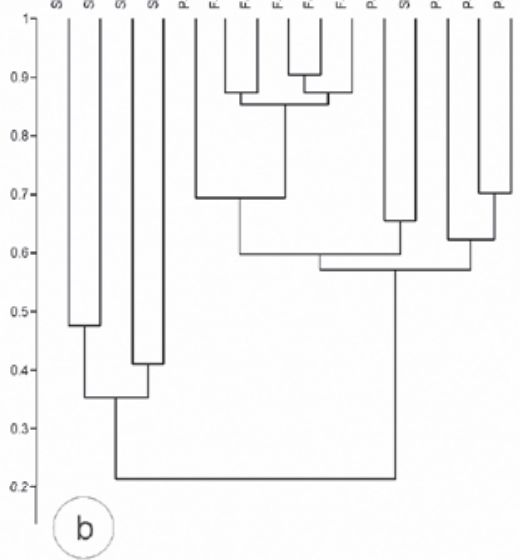

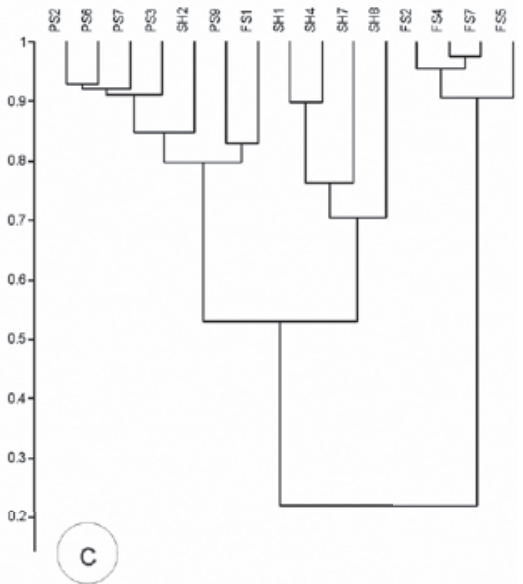

Fig. 2 - Dendrograms of the photosyntheticaly active radiation in individuals of a Bulbophyllum involutum (Orchidaceae) population growing in the Serra do Caraça, Catas Altas, Minas Gerais State, Brazil, based on photosynthetically active radiation incident on individual plants on an hourly basis during one day in July and October of 2006 and May/2007 (a), or on the sum of the PAR of these days (Daily total PAR) (b). Dendrogram based on hemispherical photographs data - LAI, direct and diffuse light transmittance (c). Light classes: "full sun" (FS), "partially shaded" (PS) and "shaded" (SH). See text for definition of the light classes. 
TABLE I

Mean and coefficient of variation (CV) of total daily photosynthetic active radiation (PAR), leaf area index (LAI), and direct and diffuse light transmittance, in population Bulbophyllum involutum (Orchidaceae) in the Serra do Caraça, Catas Altas, Minas Gerais State, Brazil. See text for definition of the light classes.

\begin{tabular}{|c|c|c|c|c|c|c|c|c|c|}
\hline \multirow{2}{*}{$\begin{array}{l}\text { Light } \\
\text { classes }\end{array}$} & \multirow[t]{2}{*}{ Months } & \multicolumn{2}{|c|}{  } & \multicolumn{2}{|c|}{ LAI } & \multicolumn{2}{|c|}{ 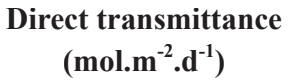 } & \multicolumn{2}{|c|}{ 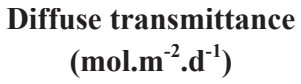 } \\
\hline & & Mean & CV & Mean & CV & Mean & CV & Mean & CV \\
\hline \multirow{3}{*}{ 'sun' } & October & 37.49 & 31.4 & - & - & - & - & - & - \\
\hline & May & 41.94 & 7.8 & - & - & 16.48 & - & 16.48 & - \\
\hline & July & 39.37 & 14.7 & - & - & 15.09 & - & 15.09 & - \\
\hline \multirow{3}{*}{$\begin{array}{l}\text { 'partially } \\
\text { shaded' }\end{array}$} & October & 14.07 & 70.9 & - & - & - & - & - & - \\
\hline & May & 22.49 & 78.1 & 0.77 & 44.9 & 11.42 & 29.0 & 9.70 & 23.7 \\
\hline & July & 23.23 & 121.7 & 0.71 & 70.9 & 11.17 & 23.8 & 9.56 & 32.3 \\
\hline \multirow{3}{*}{ 'shaded' } & October & 7.36 & 58.1 & - & - & - & - & - & - \\
\hline & May & 6.65 & 140.5 & 1.63 & 26.0 & 6.48 & 48.8 & 5.01 & 33.7 \\
\hline & & 6.48 & 165.1 & 1.79 & 26.7 & 5.91 & 53.7 & 4.18 & 33.8 \\
\hline
\end{tabular}

A scatterplot of the variables of the total daily PAR during the three analyzed seasons of the year demonstrated a structure similar to the PCA and cluster analyses, forming three discrete classes (Fig. 3). The "full sun" class received more than 35 mol.m ${ }^{-2}$. day ${ }^{-1}$ of PAR and the "partially shaded" class between 14 and 23 mol.m ${ }^{-2} \cdot$ day $^{-1}$. The "shaded" class presented less than 8 mol. $\mathrm{m}^{-2}$.day ${ }^{-1}$, equivalent to only about $20 \%$ of the incident light falling on individuals of the "full sun" class. It was noted that the individual SH2 was not included in the "shaded" class, being closest to the "partially shaded" class, as it received more incident light than the other "shaded" individuals during the entire year. The individual PS9 presented only a weak relationship with the "partially shaded" class. Once it received a little more light during July and October than the other "partially shaded" individuals, but less light during May, it was maintained in its original class.

\section{CHARACTERIZATION OF THE ENVIRONMENT BASED ON} INCIDENT LIGHT

The coefficient of variation of the total daily PAR indicated the greatest heterogeneity in the "shaded" class. It was followed by the "partially shaded" class, principally during May and July, at the beginning and at the peak of the dry season (Table I). On the other hand, as it was observed in the PCA and cluster analyses, the leaf area index indicated greater heterogeneity in the canopy which was shading individuals of $B$. involutum in the "partially shaded" class.

Despite the PAR incident on individuals within each light class did not vary significantly during the changing seasons $(p>0.05)$, the quality of the radiation (direct and diffuse light) under canopy varied within each class. During the dry season, the "partially shaded" and "shaded" classes demonstrated an increase in the heterogeneity of PAR reaching their component individuals (Table I). The direct transmittance showed an increase in the heterogeneity for "partially shaded" and "shaded" individuals. The plants belonging only to the "partially shaded" class also demonstrated an increase in the heterogeneity of the leaf area index and diffuse PAR transmittance.

The daily incident PAR received by each $a$ priori light class demonstrated wide amplitude swings during the different seasons of the year 


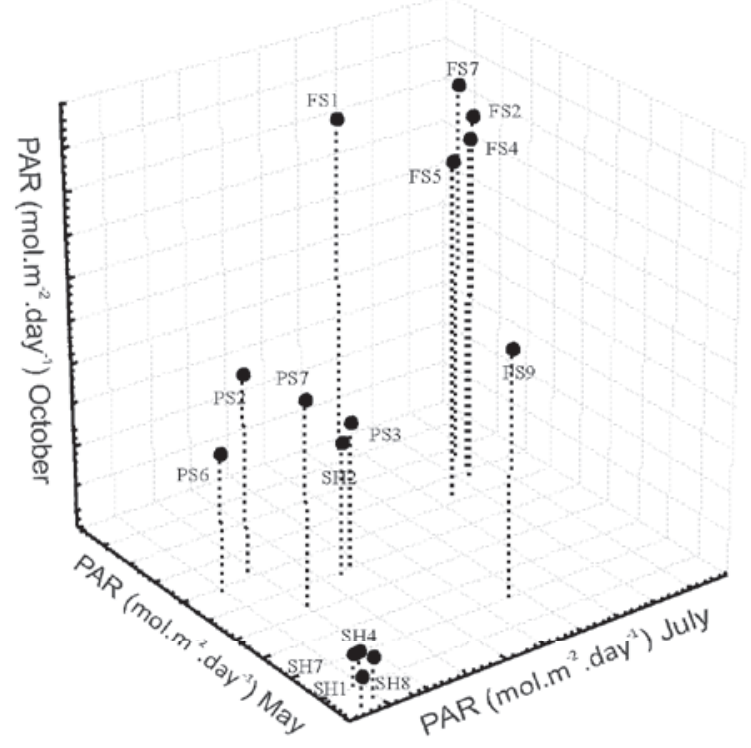

Fig. 3 - Dispersion obtained utilizing the total daily photosynthetically active radiation incident on 15 individuals of a Bulbophyllum involutum (Orchidaceae) population growing in the Serra do Caraça, Catas Altas, Minas Gerais State, Brazil, during one day in July and October of 2006, and May/2007. Light classes: "full sun" (FS), "partially shaded" (PS) and "shaded" (SH). See text for definition of the light classes.
(Fig. 4a). The initial variance of the point values measured hour by hour was typified by the incorrect a priori classification of individual $\mathrm{SH} 2$. After transferring this individual from the "shaded" to the "partially shaded" class, the variance in light incidence was reduced (Fig. 4b). The "full sun" and "shaded" classes presented low amplitude of data variation, even in the a priori classification scheme. After reclassification of the SH2 individual, a marked reduction in the standard deviation values was observed on the PAR incident on those classes, mainly at times of high light intensity, such as at $1 \mathrm{pm}$ in April.

The 15 remaining individuals evaluated during a single day in May (measuring PAR every two hours) likewise fell into the three discrete classes. Two individuals, however, were classified erroneously in the a priori evaluation: individual SH10 was transferred from "shaded" to the "partially shaded" class, and individual PS4, was transferred from "partially shaded" to the "full sun" class.


Fig. 4 - Photosynthetically active radiation incident on individuals of a Bulbophyllum involutum (Orchidaceae) population growing in the Serra do Caraça, Catas Altas, Minas Gerais State, Brazil. (a) Utilizing the 15 individuals divided arbitrarily into three a priori classes according to the incident light: "full sun" (light gray line), "partially shaded" (gray line) and "shaded" (black line), $(\mathrm{n}=5)$. (b) These 15 individuals were now organized using cluster analysis and PCA (see text), and transferred to the appropriate classes. The measurements were done in July/2006, October/2006 and May/2007. ("full sun" class, $\mathrm{n}=5$; "partially shaded", class $n=6$; "shaded" class, $n=4)$. See text for definition of the light classes. 
We found 65 genets in $240 \mathrm{~m}^{2}$ along the transect from the base of the outcrop to its highest point: $50 \%$ of the individuals belonged to the a priori "full sun" class, $35 \%$ to the "partially shaded" class, and $15 \%$ to the "shaded" class (Fig. 5a, b). Three distinct regions were observed along the transect: the first was characterized by the presence of scattered herbaceous plants and subshrubs; the second by the presence of shrubs; and the third was an area of semi-deciduous woodland. The transect shows a portion of the outcrop where there is a replacement of areas, in this case coinciding with an increase in the complexity of vegetation. Eventually, in other lowland areas of the same mountain, there is an inversion of these passages, especially I and II, but sometimes with forest, showing the heterogeneity of the site.
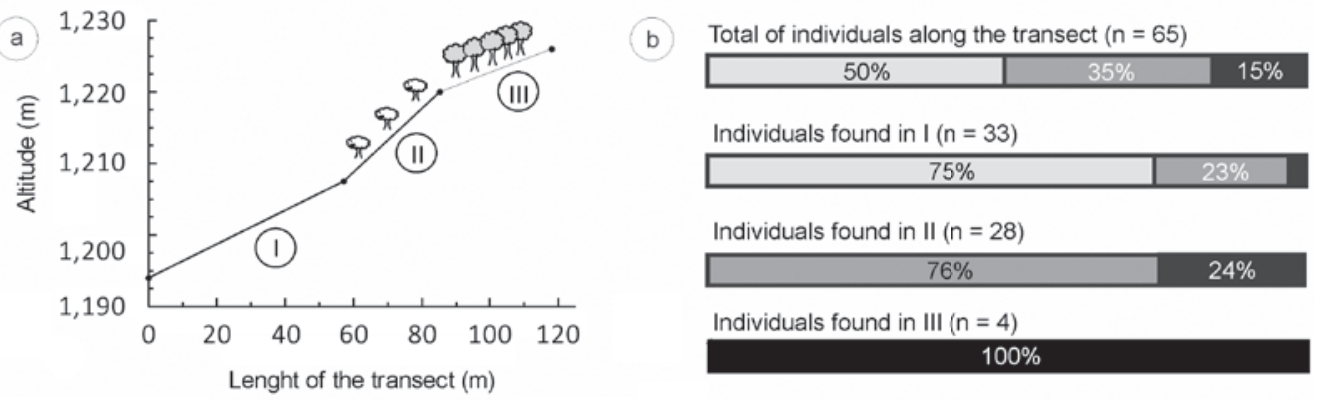

Fig. 5 - (a) Transect on the Taboões rock outcrop area in the Serra do Caraça, Minas Gerais State, Brazil. Three distinct areas of vegetation were identified: I) an open area near the base of the rocky outcrop; II) an area with a predominance of shrubs; and III) an area of semi-deciduous forest near the top of the outcrop. (b) Percentage of Bulbophyllum involutum (Orchidaceae) individuals encountered along the transect belonging to the each a priori defined class related to its exposure to photosynthetically active radiation, with (light gray) belonging to the "full sun" class, (gray) belonging to the "partially shaded" class, and (black) belonging to the "shaded" class.

\section{DISCUSSION}

\section{Light VARIATION AND THE SPATIAL DiSTRIBUTION OF}

BULBOPHYLLUM INVOLUTUM

The associations observed in the PCA, and the groups formed by the cluster analyses and by the dispersion graphs indicated the establishment and persistence of this species in various distinct light environments (although the high abundance for high sunlight situations was observed). The main elements that create heterogeneous luminosity in the study area are shrubs and subshrubs with their different architectures, shape and size of their leaves, and their phenology and the variations in micro-topography that determine different daily and seasonal exposures to PAR. These variables are also described as determinants for light heterogeneity in forest environments (Quilchano et al. 2008, Wirth et al. 2001). Light is a limiting factor for plant communities as it is a principal determinant of all of their physiological and ecological processes (Engelbrecht and Herz 2001). The crown-level clumping results in different fraction of gaps and arises due to the occurrence of crowns with different size and shapes (Valladares and Niinemets 2007). In "campo rupestre" vegetation, the mosaic formed by open field and forest formations, together with the irregular topography of the land with its many crevices in the surface rocks and scattered shrubs, makes light a heterogeneous resource, as noted for individuals of $B$. involutum. In spite of the greater frequency of $B$. involutum in niches with high irradiance, individuals were observed growing in environments having radiation flux below $8 \mathrm{~mol} \cdot \mathrm{m}^{-2} \cdot \mathrm{d}^{-1}$, suggesting that the species has significant ecophysiological amplitude (Lüttge and Scarano 2004). Herzog et al. (1999) and Lüttge and Scarano (2004) discussed this type of 
variation in their comparisons of distinct species of Clusia that could survive in shaded sites or in high solar radiation areas, or in both.

It was possible to distinguish three discrete classes of plant exposure to photosynthetically active radiation at the study site ("full sun", "partially shaded", and "shaded"). However, different levels of heterogeneity of photosynthetically active radiation (PAR) were observed within the three exposure classes examined in the present study, as could be seen in the denser PCA agglomerations of individuals in the "full sun" and "shaded" classes than in the more heterogeneous "partially shaded" class. The solar radiation flux is more dynamic in the understory than in open areas (Pearcy 2007, Valladares et al. 1997, Washitani and Tang 1991), as observed in the present study. In contrast, individuals encountered in the "partially shaded" class among subshrubs and crevices were subjected to greater heterogeneity in terms of the sunlight they received. The direct PAR transmittance increases with the frequency of sunflecks, which are the principal source of solar irradiation heterogeneity in forest understory, and alters the quality of the incident light in this environment principally during the dry season when clouds are less common (Valladares et al. 1997). Nevertheless, the inclination of the sun changes daily and seasonally, and modifies the direct and diffuse light dynamic along the day and the year.

The low variation in the light regime of the "full sun" class remained relatively constant during the year. Conversely, the beginning of the dry season heralded significant alterations in the degree of heterogeneity within the "partially shaded" and "shaded" classes. Seasonal phenological alterations in a plant community may modify the light environment, principally for herbaceous species that depend on radiation passing through the overlying canopy (Wirth et al. 2001). The heterogeneity of the PAR impinging on individuals in "partially shaded" and "shaded" sites increases during the dry season, a period marked by deciduousness of many woody savanna species (Bulhão and Figueiredo 2002, Goulart et al. 2005, Medina and Francisco 1994).

\section{EVALUATION AND ApPLICATION OF THE METHODOLOGY}

UTILIZED

Most of the studies applying the diverse methodologies in characterizing light heterogeneous environments were carried out in forest formations (Brown et al. 2000, Engelbrecht and Herz 2001, Grant 1997, Henry et al. 2002, Quilchano et al. 2008). However, studies examining patterns of light heterogeneity within vegetation forms associated with outcrops are virtually non-existent. The irregular topography common in "campo rupestre" vegetation sites, the climate, and the peculiarities of this vegetation (Caiafa and Silva 2007, Derby 1961, Krauss et al. 2008, Oliveira-Filho et al. 1989) combine to make precise evaluations of physical variables almost impossible and rigorous interpretations of ecophysiological studies much more difficult (Caiafa and Silva 2007).

The description of the light environment occupied by $B$. involutum made through PAR monitoring was aided by the use of more objective tools that allowed the delimitation of discrete classes. However, the limitations related to the restricted numbers of sites analyzed and the difficulty of monitoring them all quickly remain, and are exacerbated by difficultly of locomotion (Engelbrecht and Herz 2001). The use of multivariate analysis not only contributed to the definition of irradiance classes encountered in the study area, but also allowed the inclusion of larger number of sites in the study that could only be sampled at longer time intervals. In spite of the dense agglomerations evident in the PCA and the more cohesive groups observed in the dendrograms obtained in cluster analyses using the total daily PAR, it must be pointed out that in the former situation the variation in light intensity during the day at each site 
is masked, homogenizing any eventual differences measured at those sites. In this case, the time of day that each individual is exposed to any given light intensity is not taken into account in these analyses. Numerous studies have demonstrated the influence of the time of day on leaf metabolism, as for example in light curves alterations in species of Vellozia of the Serra do Cipó (Minas Gerais State, Brazil) recorded in the morning, at midday, and in the afternoon (Lüttge et al. 2007), and in the decarboxylation of the malic acid in plants presenting Crassulacean Acid Metabolism (CAM) (Barrow and Cockburn 1982). It is also well known that high light intensity can inhibit photosynthesis by photoinhibition (Demmig et al. 1987, Long et al. 1994, Lüttge et al. 1998, Maxwell and Johnson 2000). As such, greater or lesser exposure to sunlight during the different hours of the day can result in distinct degrees of light stress.

Hemispherical photographs are considered the most precise indirect method for characterizing light incidence in natural environments (Brown et al. 2000). However, the use of indirect methods for evaluating solar radiation are not always very efficient in localities that do not have dense vegetation covers typical of tropical forests (Engelbrecht and Herz 2001). The "campo rupestre" vegetation sites generally have very little plant cover, which may leads to a decrease in precision caused by errors in threshold of light (pointed discussed for forest formations, $c f$. Englund et al. 2000), and almost present an irregular topography which may difficult to aligning the camera. However, in a day of analysis, the camera needs to be aligned once in each individual, at the correct time, avoiding threshold effects. Furthermore, once the movement of the sun is known through hemispherical photographs, is possible to analyse the temporal variation in the contribution of direct sunlight within a day. During the year, other photographs need to be taken, eliminating the effects of biotic factors, such as phenology or attack by herbivores. Considering the difficulty of the movement of the research because this irregular topography of the "campo rupestres" sites, and the little quantum sensors disposed, the hemispherical photographs were convenient and efficient for light characterization. It detected light heterogeneity and could be considered efficient not only in forest formations, but also to characterize distinct light environments in "campo rupestres" vegetation.

The low PAR variance observed in the "full sun" class in relation to another classes was due to the lower effects of changes in the solar angle as well as the interference of the nearby small shrubs and rocks. "Shaded" and "partially shaded" classes, on the other hand, receive a gradient of incident light dependent on the heterogeneity of the matrix of shrubs and trees that intercept light differently during the course of the day and the year. The greater heterogeneity of the PAR impinging on individuals in the "partially shaded" class might be expected to generate a greater variance in their morphological and physiological characteristics. The greatest heterogeneity in PAR was observed during the dry season (when leaf loss occurs), making it difficult to accurately determine incident light classes and to choose individuals appropriate for further ecophysiological analyses. The choice of a study area and the period in which to undertake ecophysiological studies must take into account the fact that variation in the position of the sun may alter plant shading during the study, as well as the high diversity of species in tropical regions with unusual and unique phenological behaviours.

The growth of Bulbophyllum involutum across ample light gradients makes this species an interesting model for structural and ecophysiological studies, but precise characterization of the light environment is essential for an efficient experimental design and for the correct interpretation of these studies. The use of multivariate analysis was seen to be efficient in this type of study, as of the 30 individuals that were initially marked and placed a priori in the three distinct classes of incident PAR, three individuals were identified as having been classified equivocally, thus avoiding a significant error of $10 \%$. 


\section{ACKNOWLEDGMENTS}

We thank ACL Queiroz and DC Oliveira for field support. This work was supported by Fundação de Amparo à Pesquisa do Estado de Minas Gerais (FAPEMIG) (CRA 654-06), Coordenação de Aperfeiçoamento de Pessoal de Nível Superior (CAPES) (A.S.F.P. Moreira) and Conselho Nacional de Desenvolvimento Científico e Tecnológico (CNPq) (E.L. Borba and J.P. Lemos-Filho).

\section{RESUMO}

A vegetação dos Campos rupestres brasileiros apresenta alta heterogeneidade luminosa, característica muitas vezes subestimada nos estudos que abordam parâmetros ecofisiológicos devido à dificuldade de se obter medidas precisas em um ambiente tão complexo. O principal objetivo deste trabalho foi descrever o quanto a distribuição de luz neste ambiente é heterogênea e tentar definir classes com relação à radiação fotossinteticamente ativa (PAR) para 30 indivíduos rupícolas de Bulbophyllum involutum. Os indivíduos foram marcados e inseridos em classes de luz visualmente predeterminadas ("sol", "meia sombra" e "sombra"). Uma vez determinadas estas classes e com o intuito tanto de se caracterizar o ambiente de luz quanto de validar a inclusão dos indivíduos em cada classe, foram realizadas análises de componentes principais, agrupamento e dispersão, utilizando-se medidas diretas e indiretas de PAR. O uso das análises multivariadas aumentou a precisão da delimitação das classes de luz previamente determinadas e alguns indivíduos das classes "sombra" e "meia sombra" precisaram ser reagrupados em outras classes. Após esta reclassificação, a amplitude de variância da PAR reduziu dentro de cada classe, aumentando a homogeneidade. Nossos resultados mostram a possibilidade de se avaliar o ambiente de luz de forma mais precisa na vegetação dos campos rupestres através de análises multivariadas, as quais permitem um aumento na precisão deste parâmetro como base para estudos de ecofisiologia.

Palavras-chave: Bulbophyllum involutum, habitat, heterogeneidade luminosa, análise multivariada, Orchidaceae, afloramentos rochosos.

\section{REFFERENCES}

ARDitTI J. 1969. Aspects of physiology of orchids. Adv Bot Res 7: 421-655. doi:10.1016/S0065-2296(08)60091-9

BARROW SR AND COCKBURN W. 1982. Effects of light quantity and quality on the decarboxylation of malic acid in crassulacean acid metabolism photosynthesis. Plant Physiol 69: 568-571.

Benites VM, Shaefer CEGR, Simas FNB and Santos HG. 2007. Soils associated with rock outcrops in the Brazilian mountain ranges Mantiqueira and Espinhaço. Rev Bras Bot 30: 569-577.

BRANDÃo M, GAVILANES ML AND ARAÚJO MG. 1994. Aspectos físicos e botânicos de campos rupestres do Estado de Minas Gerais - 1. Daphne 4: 17-38.

Brown N, Jennings S, WheEler P AND NABe-Nielsen J. 2000. An improved method for the rapid assessment of forest understory light environments. J Appl Ecol 37: 1004-1053.

BUlHÃo CF AND FIgUeIREdo OS. 2002. Fenologia das leguminosas arbóreas em uma área de cerrado marginal no nordeste do Maranhão. Rev Bras Bot 25: 361-369.

CAIAfa NA AND Silva AF. 2007. Structural analysis of the vegetation on a highland granitic rock outcrop in Southeast Brazil. Rev Bras Bot 30: 657-664.

Demmig B, Winter K, KRÜGer A And CZygan FC. 1987. Photoinhibition and zeaxanthin formation in intact leaves. Plant Physiol 84: 218-224.

Derby AO. 1961. The Serra do Espinhaço. J Geol 14: 374-401.

Dutra GM, RubBioli EL AND HorTA LS. 2002. Gruta do Centenário, Pico do Inficcionado (Serra do Caraça), MG - A maior e mais profunda caverna quartizítica do mundo. In: Schobbenhaus $\mathrm{C}$ et al. (Eds), Sítios Geológicos e Paleontológicos do Brasil. Brasília: Departamento Nacional de Produção Mineral (DNPM/CPRM) - Comissão Brasileira de Sítios Geológicos e Paleobiológicos (SIGEP).

ENGELBRECHT BMJ AND HERZ HM. 2001. Evaluation of different methods to estimate understory light conditions in tropical forests. J Trop Ecol 17: 207-224.

ENGLUND SR, O'BRIEN JJ AND ClARK DB. 2000. Evaluation of digital and film hemispherical photography and spherical densiometry for measuring forest light environments. Can J For Res 30: 1999-2005.

FERREIRA MD, D'AsSUMPÇÃo WRC AND MAGAlHÃEs GM. 1977/1978. Nova contribuição para o conhecimento da vegetação da Cadeia do Espinhaço ou Serra Geral (Maciço do Caraça). Oréades 6: 49-67.

FRANCO ASP AND ENDO I. 2004. Sinclinal Ouro Fino revisitado, quadrilátero ferrífero, Minas Gerais: uma hipótese sobre a sua origem e evolução. Rev Bras Geoc 34: 167-174.

Gendron F, Messier C and Comeau PG. 1998. Comparision of various methods for estimating the mean growing season percent photosynthetic photon flux density in forest. Agricult Forest Meteorol 92: 55-70. 
GiUlietTI AM, HARLEY RM, QUEIROZ LP, WANDERLEY MGL AND PIRANI JR. 2000. Caracterização e endemismos nos campos rupestres da Cadeia do Espinhaço. In: Cavalcanti TB and Walter BMT (Eds), Tópicos Atuais em Botânica, Brasília: Embrapa Recursos Genéticos, p. 311-318.

Goulart MF, LEMOS-Filho JP AND LOVATO MB. 2005. Phenological variation within and among populations of Plathymenia reticulate in Brazilian Cerrado, Atlantic Forest and transitional sites. Ann Bot 96: 445-455.

GRANT RH. 1997. Partitioning of biologically active radiation in plant canopies. Int J Biometeorol 40: 26-40.

HAMMER Ø, HARPER DAT AND RYAN PD. 2001. PAST: Paleontological Statistics Software Package for Education and Data Analysis. Palaeontol Electron 4(1): 9 p. http:// palaeo-electronica.org/2001_1/past/issue1_01.htm

HenRy M, Stevens H AND CARSON WP. 2002. Resource quantity, not resource heterogeneity, maintains plant diversity. Ecol Lett 5: 420-426.

Herzog B, HofFmann S, Hartung W AND LÜtTGE U. 1999. Comparison of photosynthetic responses of the sympatric tropical $\mathrm{C}_{3}$-species Clusia multiflora H.B.K. and the $\mathrm{C}_{3}$-CAM intermediate species Clusia minor $\mathrm{L}$. to irradiance and drought stress in a phytotron. Plant Biol 1: 460-470.

Krauss KW, LOVELOCK CE, MCKeE KL, LÓPEZ-HofFMAN L, EwE DM AND SOUSA WP. 2008. Environmental drivers in mangrove establishment and early development: a review. Aquat Bot 89: 105-127.

LONG SP, HUMPHRIES S AND FALKOWISK PG. 1994 Photoinhibition of photosynthesis in nature. Ann Rev Plant Physiol Plant Mol Biol 45: 633-662.

Lüttge U, Duarte HM, Scarano FR, Mattos EA, CAVAlin PO, Franco AC AND Fernandes GW. 2007. Physiological ecology of photosynthesis of five sympatric species of Velloziaceae in the "campos rupestres" vegetation of Serra do Cipó, Minas Gerais, Brazil. Flora 202: 637-646.

LÜttge U, Haridasan M, Fernandes GW, Mattos EA, Trimborn P, FRANCO AC, CALDAS LS AND ZIELGLER H. 1998. Photosynthesis of mistletoes in relation to their host at various sites of tropical Brazil. Trees 12: 167-174.

LÜTTGE U AND SCARANO FR. 2004. Ecophysiology. Rev Bras Bot 27: 1-10.

MAXWELl K AND JOHnson GN. 2000. Chlorophyll fluorescence: a practical guide. J Exp Bot 51: 659-668.

MEdina E AND FranCISCO M. 1994. Photosynthesis and water relation of savanna tree species differing in leaf phenology. Tree Physiol 14: 1367-1381.
MitCHELL PL AND WHITMORE TC. 1993. Use of hemispherical photographs in forest ecology. O.F.I. Occasional Papers 44.

Oliveira-Filho AT, SHEPHerd GJ, MARTINS FR AND STUBBLEBINE WH. 1989. Environmental factors affecting physiognomic and floristic variation in an area of Cerrado in central Brazil. J Trop Ecol 5: 413-431.

Quilchano C, Marañón T, PÉREZ-RAmos LM, NOEJOVICH L, Valladares F AND Zavala MA. 2008. Patterns and ecological consequences of abiotic heterogeneity in manager cork oak forests of Southern Spain. Ecol Res 23: $127-139$

PEARCY RW. 2007. Responses of plants to heterogeneous light environments. In: Pugnaire F and Valladares F (Eds), Functional Plant Ecology, Boca Raton: CRC Press, p. 213-257.

RıZZINı CT. 1976. Tratado de fitogeografia do Brasil, São Paulo: Hucitec/EDUSP, 327 p.

SCARANO FR. 2007. Rock outcrop vegetation in Brazil: a brief overview. Rev Bras Bot 30: 561-568.

SMIDT EC. 2007. Filogenia e revisão taxonômica de Bulbophyllum Thours (Orchidaceae) ocorrentes no neotrópico, $\mathrm{PhD}$ Thesis, Universidade Estadual de Feira de Santana.

Valladares F, Allen MT AND PEARCy RW. 1997. Photosynthetic responses to dynamic light under field conditions in six tropical rainforest shrubs occurring along a light gradient. Oecologia 111: 505-514.

VALLADARES F AND NIINEMETS Ü. 2007. The architecture of plant crowns: from design rules to light capture and performance. In: Pugnaire $\mathrm{F}$ and Valladares $\mathrm{F}$ (Eds), Functional Plant Ecology, Boca Raton: CRC Press, p. 101-149.

WASHITANI I AND TANG Y. 1991. Microsite variation in light availability and seedling growth of Quercus serrata in a temperate pine forest. Ecol Res 6: 305-316.

WILSON SD. 2000. Heterogeneity, diversity and scale in plant communities. In: Hutchings MJ et al. (Eds), The ecological consequence of environmental heterogeneity, Oxford: Blackwell Science, p. 53-69.

Winter K, Wallace BJ, Stocker GC AND RoKsandic Z. 1983. Crassulacean acid metabolism in Australian vascular epiphytes and some related species. Oecologia 57: 129-141.

WIRTH R, WEBER B AND RYEL RJ. 2001. Spatial and temporal variability of canopy structure in a tropical moist forest. Acta Oecol 22: 235-244.

ZAR JH. 1999. Biostatistical analysis, $4^{\text {th }}$ ed., New Jersey: Prentice Hall, 662 p. 